\title{
Pertumbuhan Tomat pada Frekuensi Pengairan yang Berbeda
}

\section{Growth of Tomato on A Different Watering Frequency}

\author{
Riana Jumawati ${ }^{1)}$, Amalia Tetrani Sakya ${ }^{2)}$, Muji Rahayu ${ }^{2)}$
}

\begin{abstract}
Tomato (Lycopersicum esculentum Mill) is one of horticulture commodities with high economic value and still need seriously handling especially for increasing fruits quality and quantity. However the production of tomato has not fullfilleed the demand yet. Therefore it is necessary to develop production. On lowland, the issue not only high temperature but also availability of water is unpredictable. This study aimed to investigate the effect of irrigation frequency on the growth of Mutiara, Opal, and Gondol tomato variety. This research was conducted at the Greenhouse Laboratory of the Agriculture Faculty, Sebelas Maret University with attitude $95 \mathrm{~m}$ asl. Implementation of the research conducted from January to May 2013. This research used completely randomized factorial design with two factors, namely variety of tomato (Gondol, Opal and Mutiara) and watering frequencies (everyday, once in 3 days, once in 6 days, and once in 9 days). The results showed that plant height, number of leaves and number of branches are influenced by the variety of tomato and irrigation frequency, whereas chorophyl content is influenced by the watering frequency. Growth component and chlorophyll content of tomato decreased with increasing irrigation frequency.
\end{abstract}

Keywords : variety of tomatoes, watering frequency, water stress

\section{PENDAHULUAN}

Tomat (Lycopersicum esculentum Mill) merupakan salah satu komoditas hortikultura yang bernilai ekonomi tinggi dan masih memerlukan penanganan serius, terutama dalam hal peningkatan hasil dan kualitas buah. Produktivitas tomat di Indonesia masih rendah, yaitu 15,75 ton $\mathrm{ha}^{-1}$ (DEPTAN 2013). Perluasan pengembangan ke dataran rendah perlu dilakukan untuk memenuhi permintaan pasar karena produksi dataran tinggi tidak mencukupi.

Kualitas dan hasil rendah karena penanaman kurang memperhatikan kualitas sehingga penelitian perlu diarahkan untuk meningkatkan hasil dan kualitas buah tomat. Permasalahan pengembangan tomat di dataran rendah selain suhu tinggi adalah ketersediaan air yang pada fase pertumbuhan dan perkembangan tanaman tidak terpenuhi, maka tanaman akan kekurangan air. Kekurangan air akan mengakibatkan tanaman mengalami stress dimana tanaman tidak mampu menyerap air untuk menggantikan kehilangan akibat transpirasi sehingga terjadi kelayuan, gangguan pertumbuhan bahkan kematian (FAO 2007).

Wudiri dan Henderson (1985) menyatakan bahwa air yang cukup dapat meningkatkan hasil buah tomat sebesar 55-87\%. Lestari (2003) mengemukakan bahwa tanaman famili Solanaceae sangat rentan terhadap kekurangan dan kelebihan air selama masa pertumbuhan. Oleh karena itu perlu diketahui batasan taraf pemberian air dan frekuensi pemberian air yang sesuai terhadap tanaman tomat agar dapat

\footnotetext{
1) Undergraduate Student of Study Program of Agrotechnology, Agriculture Faculty University of Sebelas Maret (UNS) Surakarta.

2) Lecturer of Study Program of Agrotechnology, Agriculture Faculty University of Sebelas Maret (UNS) Surakarta.
}

Contac Author: sakya_at@yahoo.com mempercepat pertumbuhan, produksi dan kualitas buah tomat.

\section{METODE PENELITIAN}

Penelitian ini dilaksanakan pada bulan Desember 2012 sampai bulan Mei 2013 bertempat di Rumah Kaca (Green house) Fakultas Pertanian Universitas Sebelas Maret Surakarta. Bahan yang digunakan pada adalah benih tomat varietas Opal, Gondol, dan Mutiara, tanah, air, pupuk kandang, pupuk urea, SP36 , pupuk $\mathrm{KCl}$, larutan $\mathrm{NaOH}$, larutan amilum $1 \%$, PP dan larutan iodin standar 0,01 N. Alat yang digunakan dalam penelitian ini antara lain timbangan analitik, bak persemaian, penggaris/mistar, gelas ukur, polibag, oven, klorofilmeter, mortar, cuvet, kertas saring, pinboard, labu Erlenmeyer, labu ukur $100 \mathrm{ml}$ dan Hand Refraktometer

Penelitian ini disusun secara faktorial dengan menggunakan Rancangan Acak Lengkap (RAL) yang terdiri dari dua faktor perlakuan. Faktor pertama adalah varietas tomat (Gondol, Opal, Mutiara) sedangkan faktor kedua adalah frekuensi pemberian air (setiap hari, 3 hari, 6 hari, 9 hari) sehingga terdapat 12 kombinasi yang masing - masing diulang 4 kali. Variabel yang diamati antara lain: tinggi tanaman, luas daun, jumlah cabang, panjang akar, berat biomassa, kandungan klorofil, rasio tajuk akar. Data dianalisis menggunakan analisis ragam dengan uji $F$ taraf $5 \%$, dan jika beda nyata dilanjutkan dengan DMRT taraf $5 \%$.

\section{HASIL DAN PEMBAHASAN}

\section{Komponen Pertumbuhan}

\section{Tinggi Tanaman}

Salah satu yang sering diamati untuk dijadikan indikator pertumbuhan maupun parameter untuk mengukur pengaruh lingkungan atau perlakuan yang 
diterapkan adalah tinggi tanaman. Ini didasarkan pada kenyataan bahwa tinggi tanaman merupakan ukuran yang paling mudah dilihat (Sitompul dan Guritno 1995). Hasil analisis ragam menunjukkan bahwa varietas dan frekuensi pemberian air berpengaruh sangat nyata terhadap tinggi tanaman serta terjadi interaksi antara varietas dan frekuensi pemberian air.

Tabel 1. Pengaruh varietas tomat dan frekuensi pemberian air terhadap tinggi tanaman pada umur 15 MST $(\mathrm{cm})$

\begin{tabular}{llllll}
\hline \multirow{2}{*}{ Varietas } & \multicolumn{5}{c}{ Frekuensi Pemberian Air } \\
\cline { 2 - 5 } & 1 Hari (P1) & 3 Hari (P2) & 6 Hari (P3) & 9 Hari (P4) & \\
\hline Gondol (A1) & $149,00^{\mathrm{ab}}$ & $172,75^{\mathrm{bc}}$ & $128,12^{\mathrm{a}}$ & $113,00^{\mathrm{a}}$ & 140,72 \\
Opal (A2) & $174,75^{\mathrm{bc}}$ & $197,75^{\mathrm{c}}$ & $145,25^{\mathrm{ab}}$ & $122,25^{\mathrm{a}}$ & 160,00 \\
Mutiara (A3) & $194,50^{\mathrm{c}}$ & $210,00^{\mathrm{c}}$ & $150,25^{\mathrm{ab}}$ & $135,13^{\mathrm{ab}}$ & 172.47 \\
\hline Rerata & 172,75 & 193,50 & 141,21 & 123,46 & + \\
\hline
\end{tabular}

Keterangan: Angka yang diikuti huruf sama dalam satu baris menunjukkan tidak beda nyata pada DMRT 5\%. (+) terdapat interaksi.

Tabel 1 menunjukkan varietas Mutiara dengan frekuensi pemberian air 3 hari menghasilkan tanaman tertinggi $(210 \mathrm{~cm})$ yang berbeda nyata dengan frekuensi pemberian air 6 dan 9 hari sedangkan varietas Gondol frekuensi pemberian air 9 hari menghasilkan tinggi terendah $(113 \mathrm{~cm})$ yang berbeda nyata dengan frekuensi pemberian air setiap hari dan 3 hari. Pemberian air 9 hari tinggi tidak maksimal karena suplai air ke dalam tanaman tidak mencukupi, sehingga fotosintesis tidak maksimal dan pertumbuhan tanaman terhambat. Apabila ketersedian air kurang maka hasil fotosintesis akan berkurang sehingga asupan makanan untuk pertumbuhan berkurang. Ketersediaan air yang tidak mencukupi menyebabkan terhambatnya pertumbuhan tanaman. Ketersediaan air di dalam tanah merupakan salah satu faktor lingkungan abiotik yang paling berpengaruh terhadap pertumbuhan dan produksi tanaman (Dzajuli 2010).

\section{Luas Daun}

Luas daun merupakan salah satu indikator pertumbuhan tanaman yang cukup peka terhadap defisit air sebab daun merupakan organ tanaman untuk berfotosintesis yang mengubah energi cahaya menjadi energi kimia dan diakumulasikan dalam bentuk kering. Berdasarkan hasil analisis ragam dapat diketahui bahwa varietas dan frekuensi berpengaruh sangat nyata terhadap luas daun tanaman tomat serta terjadi interaksi antara kedua perlakuan.

Pada Tabel 2 dapat diketahui bahwa varietas Mutiara dengan frekuensi pemberian air setiap hari memiliki nilai luas daun tertinggi yaitu sebesar 250,92 $\mathrm{cm}^{2}$, nilai tersebut berbeda nyata dengan pemberian air 3 hari sekali, 6 hari sekali, dan 9 hari. Nilai luas daun terendah sebesar $54,81 \mathrm{~cm}^{2}$ terdapat pada perlakuan pemberian air 9 hari sekali dengan varietas Opal. Nilai tersebut berbeda nyata pada varietas yang sama dengan frekuensi pemberian air 6 hari sekali, 3 hari sekali dan setiap hari. Varietas Gondol pada frekuensi pemberian air 6 hari sekali dan 9 hari sekali dengan nilai $61,94 \mathrm{~cm}^{2}$ dan $60,13 \mathrm{~cm}^{2}$ berbeda nyata dengan pemberian air setiap hari dan 3 hari sekali yaitu $105,65 \mathrm{~cm}^{2}$ dan $113,23 \mathrm{~cm}^{2}$. Varietas Mutiara merupakan varietas dengan ukuran daun besar dengan pemberian air cukup maka daun tanaman akan berkembang dengan maksimal. Berbeda dengan varietas Opal dan Gondol, keduanya memiliki bentuk daun lebih kecil dibanding Mutiara. Namun dengan kebutuhan air yang tercukupi maka perkembangan daun menjadi maksimal. Diduga penurunan ukuran luas daun sebagai upaya tanaman untuk mempertahankan diri untuk tetap hidup dalam kondisi kekurangan air.

Tabel 2. Pengaruh varietas dan frekuensi pemberian air terhadap luas daun tanaman pada umur $15 \mathrm{MST}\left(\mathrm{cm}^{2}\right)$

\begin{tabular}{llllll}
\hline \multirow{2}{*}{ Varietas } & \multicolumn{5}{c}{ Frekuensi Pemberian Air } \\
\cline { 2 - 5 } & 1 hari(P1) & 3 hari (P2) & 6 hari (P3) & 9 hari (P4) & \\
\hline Gondol (A1) & $105,65^{\mathrm{b}}$ & $113,23^{\mathrm{b}}$ & $61,94^{\mathrm{a}}$ & $60,13^{\mathrm{a}}$ & 85,24 \\
Opal (A2) & $169,92^{\mathrm{c}}$ & $231,37^{\mathrm{de}}$ & $101,71^{\mathrm{b}}$ & $54,81^{\mathrm{a}}$ & 139,45 \\
Mutiara (A3) & $250,92^{\mathrm{e}}$ & $203,77^{\mathrm{d}}$ & $125,58^{\mathrm{b}}$ & $61,37^{\mathrm{a}}$ & 149,16 \\
\hline Rerata & 175,5 & 182,79 & 96,41 & 58,77 & + \\
\hline
\end{tabular}

Keterangan: Angka yang diikuti huruf sama dalam satu baris menunjukkan tidak beda nyata pada DMRT 5\%. (+) terdapat interaksi.

Menurut Goldworthy dan Fisher (1984), adanya cekaman kekeringan seringkali mengakibatkan penurunan luas daun yang biasanya akan mengurangi laju kehilangan air dan menunda permulaan kekurangan air yang lebih berat. Kekurangan air mengakibatkan penurunan pembentukan dan perluasan daun serta memacu penuaan dan perontokan daun. Hidayati dalam Sukarman et al. (2000) melaporkan bahwa Vicia faba yang diberi perlakuan cekaman kekeringan akan menunjukkan respon fisiologis daun yaitu menutupnya stomata, menurunnya jumlah dan luas daun. Sebelumnya Whigham dan Minor (1978), melaporkan bahwa pengaruh cekaman air pada pertumbuhan 
tanaman dicerminkan oleh daun-daun yang lebih kecil.

\section{Jumlah Cabang}

Jumlah cabang produktif yang lebih banyak, produktivitas tanaman akan meningkat. Jumlah cabang merupakan variabel penting dalam penelitian ini, sebab pada cabang akan muncul bunga sehingga apabila cabang yang terbentuk cukup banyak maka hasil akan berbanding lurus. Selain itu, apabila cabang yang terbentuk banyak maka jumlah daun juga akan tinggi sehingga hasil fotosintesis lebih banyak. Ini mengakibatkan pertumbuhan tanaman menjadi baik. Berdasarkan analisis ragam diketahui bahwa varietas dan frekuensi pemberian air berpengaruh sangat nyata terhadap jumlah cabang tanaman tomat serta terjadi interaksi antara varietas dan frekuensi pemberian air.

Tabel 3. Pengaruh varietas tomat dan frekuensi pemberian air terhadap jumlah cabang tanaman pada umur 15 MST

\begin{tabular}{lllllc}
\hline \multirow{2}{*}{ Varietas } & \multicolumn{5}{c}{ Frekuensi Pemberian Air } \\
\cline { 2 - 5 } & 1 hari(P1) & 3 hari (P2) & 6 hari (P3) & 9 hari (P4) & \\
\hline Gondol (A1) & $3,25^{\mathrm{bc}}$ & $3,75^{\mathrm{c}}$ & $2,00^{\mathrm{ab}}$ & $2,25^{\mathrm{ab}}$ & 2,81 \\
Opal (A2) & $1,50^{\mathrm{a}}$ & $3,25^{\mathrm{bc}}$ & $1,50^{\mathrm{a}}$ & $1,25^{\mathrm{a}}$ & 1,88 \\
Mutiara (A3) & $3,00^{\mathrm{bc}}$ & $3.25^{\mathrm{bc}}$ & $2,25^{\mathrm{ab}}$ & $2,50^{\mathrm{abc}}$ & 2,75 \\
\hline Rerata & 2,58 & 3,42 & 1,92 & 2,00 & + \\
\hline
\end{tabular}

Keterangan: Angka yang diikuti huruf sama dalam satu baris menunjukkan tidak beda nyata pada DMRT $5 \%$.

(+) terdapat interaksi.

Pada Tabel 3 terlihat bahwa nilai tertinggi $(3,75)$ pada varietas Gondol pada frekuensi pemberian air 3 hari yang beda nyata dengan frekuensi pemberian air 6 dan 9 hari sedangkan nilai terendah $(1,5)$ terdapat pada varietas Opal yang beda nyata dengan frekuensi pemberian air 3 hari pada semua varietas serta varietas Gondol dan Mutiara frekuensi pemberian air setiap hari. Menurut Harjadi dalam Hartati (2000), terhambatnya pertumbuhan akan mengakibatkan tanaman tumbuh rendah, sehingga dengan kurang tersedianya air jumlah cabang tanaman tomat akan menjadi sedikit. Selain itu, tanaman kekurangan air dalam jangka waktu lama dapat mengakibatkan penurunan laju translokasi fotosintesa ke bagian organ penumpukan, misalnya pembentukan buah, sehingga buah lama terbentuk.

\section{Panjang Akar}

Sistem perakaran yang berbeda antara varietas toleran dan peka kekeringan mengindikasikan bahwa sistem perakaran mempunyai arti penting bagi kedelai dalam proses adaptasi terhadap stres kekeringan (Hamim et al. 1996). Air yang dibutuhkan oleh tanaman diambil dari air dalam tanah melalui sistem perakaran. Oleh karena itu ukuran akar, kerapatan akar, dan aktivitas akar sangat berpengaruh dalam penyerapan air. Hasil analisis ragam menunjukkan bahwa varietas tidak berpengaruh nyata terhadap panjang akar sedangkan frekuensi pemberian air berpengaruh sangat nyata terhadap panjang akar tanaman tomat dan tidak terjadi interaksi antara varietas dan frekuensi pemberian air.

Pada Tabel 4 terlihat bahwa pada frekuensi pemberian air 3 hari sekali memberikan nilai $23,52 \mathrm{~cm}$ yang berbeda nyata dengan frekuensi pemberian air 6 dan 9 hari sekali namun tidak berbeda nyata dengan rerata pada frekuensi pemberian air setiap hari. Pada dasarnya perakaran tanaman dengan frekuensi pemberian air dengan jangka waktu lebih lama akan terlihat lebih pendek dan rambut akar lebih sedikit. Tanaman yang peka terhadap kekeringan mengalami penurunan baik panjang maupun berat kering akar, sedangkan varietas toleran justru sebaliknya mengalami penambahan panjang akar selama stress kekeringan (Mitra 2001).

Varietas tomat pun mempengaruhi dalam penghindaran kekeringan seperti yang disampaikan Burch et al. (1978) pada penelitinnya mengenai kedelai, dimana telah diketahui bahwa keragaman genetik kedelai mempengaruhi kemampuan menghindar dari kekeringan dengan menyempitkan kedalaman dan volume perakaran.

\section{Berat Biomassa}

Penggunaan berat biomassa tanaman, sebagai penentu uji toleransi tanaman terhadap cekaman kekeringan sejalan dengan pendapat Blum (1996) yang menyatakan bahwa pada saat pasokan air tidak mencukupi kebutuhan evapotranspirasi dan asimilasi cenderung menurun. Hasil analisis ragam diketahui bahwa varietas tidak berpengaruh nyata terhadap berat biomassa sedangkan frekuensi pemberian air berpengaruh sangat nyata terhadap biomassa kering tanaman tomat serta terjadi interaksi antara varietas dan frekuensi pemberian air.

Tabel 5 menunjukkan bahwa frekuensi pemberian air 3 hari sekali berbeda nyata dengan frekuensi pemberian air setiap hari, 6 hari sekali, dan 9 hari sekali. Schutz dan Fangmeir (2001) melaporkan bahwa cekaman kekeringan pada gandum dapat menurunkan biomassa tajuk sebesar $40 \%$. Penurunan berat biomassa diduga karena penurunan laju fotosintesis akibat rendahnya asimilasi $\mathrm{CO}_{2}$ akibat penutupan stomata. Kekurangan air menurunkan perkembangan vegetatif dan hasil panen dengan cara mengurangi pengembangan daun dan penurunan fotosintesis daun yang berakibat menurunnya fotosintesis tajuk (Gardner et al. 1985). 


\section{Komponen Fisiologi}

\section{Kadar Klorofil}

Pengukuran karakter fisiologi seperti kandungan klorofil merupakan salah satu pendekatan untuk mempelajari pengaruh kekurangan air terhadap pertumbuhan dan hasil produksi karena parameter ini berkaitan erat dengan laju fotosintesis (Li et al. 2006).

Tabel 4. Pengaruh varietas dan frekuensi pemberian air terhadap panjang akar tanaman pada umur $15 \mathrm{MST}(\mathrm{cm})$

\begin{tabular}{llllll}
\hline \multirow{2}{*}{ Varietas } & \multicolumn{5}{c}{ Frekuensi Pemberian Air } \\
\cline { 2 - 5 } & 1 hari(P1) & 3 hari (P2) & 6 hari (P3) & 9 hari (P4) & \\
\hline Gondol (A1) & 17,50 & 21,78 & 13,35 & 11,40 & 16,01 \\
Opal (A2) & 15,10 & 27,90 & 16,50 & 11,95 & 17,86 \\
Mutiara (A3) & 29,13 & 20,88 & 18,73 & 12,40 & 20,29 \\
\hline Rerata & $20,58^{\mathrm{bC}}$ & $23,52^{\mathrm{C}}$ & $16,19^{\mathrm{ab}}$ & $11,92^{\mathrm{a}}$ & - \\
\hline
\end{tabular}

Keterangan: Angka yang diikuti huruf sama dalam satu baris menunjukkan tidak beda nyata pada DMRT 5\%. (-) tidak terdapat interaksi.

Tabel 5. Pengaruh varietas dan frekuensi pemberian air terhadap berat biomassa tanaman pada umur 15 MST (gram)

\begin{tabular}{llllll}
\hline \multirow{2}{*}{ Varietas } & \multicolumn{5}{c}{ Frekuensi Pemberian Air } \\
\cline { 2 - 5 } & 1 hari(P1) & 3 hari (P2) & 6 hari (P3) & 9 hari (P4) & \\
\hline Gondol (A1) & 24,85 & 27,26 & 23,86 & 13,11 & 22,27 \\
Opal (A2) & 14,03 & 36,32 & 14,21 & 14,64 & 20.30 \\
Mutiara (A3) & 20,95 & 32.04 & 27,80 & 12,63 & 23,36 \\
\hline Rerata & $19,94^{\mathrm{a}}$ & $31,87^{\mathrm{b}}$ & $21,96^{\mathrm{a}}$ & $13,46^{\mathrm{a}}$ & -
\end{tabular}

Keterangan: Angka yang diikuti huruf sama dalam satu baris menunjukkan tidak beda nyata pada DMRT $5 \%$. (-) tidak terdapat interaksi.

Salah satu aspek fotosintesis yang paling sentitif terhadap kekurangan air adalah biosintesis klorofil dan pembentukan proto klorofil terhambat pada potensial air sedikit dibawah 0 atm (Salisbury dan Ross 1992). Hasil analisis ragam menunjukkan bahwa varietas tidak berpengaruh nyata terhadap kadar klorofil tanaman tomat namun frekuensi pemberian air berpengaruh nyata terhadap kandungan klorofil pada tanaman tomat serta terjadi interaksi antara varietas dan frekuensi pemberian air.

Pada Tabel 6 diketahui bahwa pada frekuensi pemberian air 3 hari sekali memberikan rerata 51,93 yang berbeda nyata dengan rerata frekuensi pemberian air setiap hari namun tidak berbeda nyata dengan rerata pada frekuensi pemberian air 6 dan 9 hari sekali. Menurut Hendriyanti dan Setiani (2009), kadar air yang rendah menyebabkan pengangkutan ammonium kurang optimal. Selain itu, kandungan air yang rendah dalam media tanam secara langsung juga akan menghambat sintesis klorofil pada daun. Ketersediaan air yang kurang menyebabkanlaju fotosintesis menurun yang mengakibatkan sintesis klorofil menurun. Kekurangan air juga menyebabkan kenaikan temperatur dan transpirasi sehingga menyebabkan disintegrasi klorofil, sedangkan tingginya klorofil pada tanaman yang tercekam mengakibatkan kloroplas tinggi sehingga klorofil tanaman tinggi.

Tabel 6. Pengaruh varietas tomat dan frekuensi pemberian air terhadap kadar klorofil tanaman pada umur 9 MST

\begin{tabular}{llllll}
\hline \multirow{2}{*}{ Varietas } & \multicolumn{5}{c}{ Frekuensi Pemberian Air } \\
\cline { 2 - 5 } & 1 hari(P1) & 3 hari (P2) & 6 hari (P3) & 9 hari (P4) & Rerata \\
\hline Gondol (A1) & 43,66 & 50,38 & 52,80 & 53,20 & 50,01 \\
Opal (A2) & 44,73 & 53,74 & 49,23 & 50,50 & 49,55 \\
Mutiara (A3) & 45,77 & 51,67 & 51,54 & 45,22 & 48,55 \\
\hline Rerata & $44,72^{\mathrm{a}}$ & $51,93^{\mathrm{b}}$ & $51,19^{\mathrm{b}}$ & $49,64^{\mathrm{ab}}$ & + \\
\hline
\end{tabular}

Keterangan: Angka yang diikuti huruf sama dalam satu baris menunjukkan tidak beda nyata pada DMRT $5 \%$. (-) tidak terdapat interaksi.

\section{Rasio Tajuk Akar}

Rasio tajuk akar digunakan untuk mengetahui kemampuan tumbuhan dalam mempertahankan keseimbangan fungsional di lingkungan yang mengalami cekaman. Rasio tajuk-akar bersifat plastis, nilainya akan meningkat pada kondisi ketersediaan air, nitrogen, oksigen, dan suhu yang rendah (Fitter dan Hay 1998). Berdasarkan hasil analisis ragam diketahui bahwa varietas maupun frekuensi pemberian air tidak berpengaruh nyata terhadap ratio tajuk akar tanaman tomat serta tidak terjadi interaksi antara varietas dan frekuensi pemberian air. 
Tabel 7. Pengaruh varietas tomat dan frekuensi pemberian air terhadap rasio tajuk akar tanaman pada umur $15 \mathrm{MST}$

\begin{tabular}{llllll}
\hline \multirow{2}{*}{ Varietas } & \multicolumn{5}{c}{ Frekuensi Pemberian Air } \\
\cline { 2 - 5 } & 1 hari(P1) & 3 hari (P2) & 6 hari (P3) & 9 hari (P4) & \\
\hline Gondol (A1) & 3,31 & 4,82 & 4,18 & 8,32 & 5,16 \\
Opal (A2) & 4,35 & 4,75 & 7.15 & 4,34 & 5,15 \\
Mutiara (A3) & 4,89 & 4.34 & 5,78 & 4,24 & 4,81 \\
\hline Rerata & 4,18 & 4,64 & 5,70 & 5,64 & - \\
\hline
\end{tabular}

Keterangan: Angka yang diikuti huruf sama dalam satu baris menunjukkan tidak beda nyata pada DMRT 5\%. (-) tidak terdapat interaksi.

Pada Tabel 7 menunjukkan bahwa rasiotajuk akar tidak berbeda nyata baik pada varietas maupun frekuensi pemberian air. Beberapa tanaman tomat dengan pemberian air setiap hari mengalami pertumbuhan stagnan sehingga tidak terjadi pertambahan tinggi dan akar juga tidak berkembang. Hal ini terjadi karena keadaan tanah terlalu basah. Sedangkan tanaman dengan pemberian air 9 hari sekali pertumbuhan tinggi terhambat dan terdapat satu tanaman mengalami kematian akibat kekurangan air dan terserang hama kutu putih. Rasio tajuk-akar dapat menggambarkan salah satu tipe toleransi terhadap adanya kekeringan. Rasio tajuk akar dikendalikan oleh faktor genetik maupun faktor lingkungan (Gardner et al 1991). Frekuensi berpengaruh terhadap hasil dan kualitas buah. Semakin tinggi frekuensi pemberian air maka bobot total buah semakin besar dan jumlah buah semakin banyak.

\section{KESIMPULAN DAN SARAN}

\section{Kesimpulan}

1. Frekuensi pemberian air 9 hari sekali pada tanaman tomat menurunkan tinggi tanaman, luas daun, jumlah cabang, panjang akar, kadar klorofil, dan berat biomassa namun menaikkan rasio tajuk akar tanaman.

2. Frekuensi pemberian air 3 hari sekali pada tanaman tomat merupakan penyiraman terbaik untuk mendapatkan pertumbuhan dan hasil yang optimal.

3. Semakin jarang tanaman tomat disiram menurunkan komponen pertumbuhan dan komponen fisiologis namun menaikkan kualitas buah.

4. Varietas yang paling tahan terhadap cekaman kekeringan adalah varietas Opal.

\section{Saran}

Saran yang dapat diberikan terhadap penelitian adalah :

1. Pemberian air tanaman tomat 3 hari sekali diperlukan untuk mendapatkan pertumbuhan optimal.

2. Perlu adanya penelitian lebih lanjut mengenai cekaman kekeringan dengan varietas yang berbeda agar dapat mengetahui varietas yang paling tahan terhadap cekaman.

\section{DAFTAR PUSTAKA}

Blum A. 1996. Crop responses to drought and the interpretation of adaptation. Plant Growth Reg 20: 135-148.

Burch GJ, Smith RCG, Mason WK. 1978. Agronomic and physiological responses of soybeans and sorghum crops to water deficits. II. Crop Evaporation, Soil Water Depletion and Root Distribution. Aust. J Plant Phy 5: 169-177.

Departemen Pertanian [DEPTAN]. 2013. Subsektor holtikultura. http://www.deptan.go.id.htmv/. Diakses pada tanggal 19 Januari 2014.

Djazuli, Muhammad. 2010. Pengaruh cekaman kekeringan terhadap pertumbuhan dan beberapa karakter Morfo-Fisiologis tanaman nilam. Bul. Littro 21 (1): 8-17.

FAO [Food and Agriculture Organization]. 2007. Glosarry. Fao.org. Available from http://www.fao. org/docrep/003/x3910E26.htm. Diakses pada tanggal 21 Mei 2012.

Fitter AH, Hay RKM. 1998. Fisiologi lingkungan tanaman. Yogyakarta (ID): Gadjah Mada University Press.

Gardner F, Pearce R, Mitchell RL. 1985. Physiology of crop plants. Iowa State University Press, Ames, USA, pp: 66.

Gardner FP, Pearce RB, Mitchell RI. 1991. Phisiology of crops plants. Terjemahan Subiyanto dan Susilo (editor). Fisiologi tanaman budidaya. Jakarta (ID): UI Press.

Goldworthy PR, Fisher NM. 1992. Fisiologi tanaman budaya tropik. Diterjemahkan oleh Tohari. Gadjah Mada University Press. 874 hal.

Hamim DS, Yusuf M. 1996. Beberapa karakteristik morfologi dan fisiologi kedelai toleran dan peka terhadap cekaman kekeringan. Hayati 3 (1): 30-34.

Harjadi SS. 1979. Pengantar agronomi. Jakarta (ID): Gramedia.

Hartati Sri. 2000. Penampilan genotip tanaman tomat (Lycopersicum esculentum Mill.) hasil mutasi buatan pada kondisi stress air dan kondisi optimal. Agrosains 2 (2): 35-42.

Lestari E. 2003. Simulasi potensi hasil dan pengaruh cekaman air pada tanaman kentang (Solanum tuberosum L.) di Kecamatan Lembang Kabupaten Bandung. Skripsi. IPB. Bogor. 26 hal. 
Hendriyani IS, Setiani N. 2009. Kandungan klorofil dan pertumbuhan kacang panjang (Vigna sinensis) pada tingkat penyediaan air yang berbeda. J Sains \& Mat 17 (3): 145-150.

Guo LIRP, Baum M, Grando S, Ceccarelli S. 2006. Evaluation of chlorophyll content and fluorescence parameters as indicators of drought tolerance in Barley. Agric Sci in China 5 (10): 751-757.
Mitra J. 2001. Genetics and genetic improvement of drought resistance in crop. Current Sci 80 (6): 758763.

Salisbury FB, Ross CW. 1995. Fisiologi tumbuhan. Jilid I. Bandung (ID): Penerbit ITB, Bandung. 241 hal. 